\title{
Vidas como produto de invenção: uma análise da escrita de Fernando Sabino como biógrafo e autobiógrafo
}

Vivian Bezerra da Silva" Fátima Cristina Dias Rocha*"

\section{Resumo}

Este artigo tem por intuito contribuir para as pesquisas no âmbito das escritas de si ao analisar a obra do escritor Fernando Sabino, autor que utilizou constantemente a vida como produto de invenção literária. Para tal objetivo, será investigado o teor autobiográfico que permeia a obra do escritor mineiro a partir de dois livros seus: o esboço de autobiografia $O$ tabuleiro de damas (1988) e o livro de perfis Gente (1975). Na autobiografia, observaremos que Fernando Sabino privilegia o relato de suas experiências literárias em detrimento das pessoais, contribuindo assim para a construção de uma imagem autoral. Em diversas passagens da narrativa é possível verificar, também, o desvio do foco para a descrição de outras personalidades ao passo que no livro Gente, em que a proposta é evidenciar o outro, há, muitas vezes, a representação daquele que escreve. Assim, este trabalho não se limita à escrita autobiográfica de Fernando Sabino, mas também analisa outra faceta do autor: a biográfica.

Palavras-chave: Fernando Sabino. Autobiografia. Biografia. Autoimagem.

\section{Considerações iniciais}

Observamos, na contemporaneidade, que as escritas de si atingiram uma relevância raras vezes alcançada anteriormente: além das formas clássicas - correspondências, memórias, diários íntimos e autobiografia -, surgiram novas modalidades de manifestações do eu: blogs, vlogs, entrevistas, autoficção, entre outros formatos, abrindo um vasto campo de estudos para investigações.

Devido ao advento tecnológico e ao avanço dos meios de comunicação, as formas de escrita e/ou exposição de si desenvolvem-se cada vez mais. Hoje,

* Mestra em Literatura Brasileira pela Universidade Estadual do Rio de Janeiro. E-mail: letras.vivian@ gmail.com

** Doutora em Literatura Brasileira pela Universidade Federal do Rio de Janeiro. Professora no Instituto de Letras da Universidade do Estado do Rio de Janeiro. E-mail: fanalu@terra.com.br

Data de submissão: mar. 2016 - Data de aceite: maio 2016 http://dx.doi.org/10.5335/rdes.v12i1.5835 
existem maneiras várias de se autoconstruir artisticamente, e verifica-se, de modo gradativo, uma procura do público por indícios de realidade nas diferentes manifestações culturais e literárias. Também, como nos dias atuais, nunca foi tão fácil o acesso à informação sobre a vida de qualquer personalidade.

O autor contemporâneo, consciente dessa tendência, muitas vezes, embaralha propositalmente as fronteiras entre realidade e ficção, provocando, assim, um desvelar de si mesmo à medida que se mantém à sombra.

Constatamos, assim, que as fronteiras entre os gêneros estão cada vez mais tênues, escapando de definições. Tal aspecto pode ser observado na obra de um dos mais atuantes escritores brasileiros do século XX, Fernando Sabino.

Este artigo, considerando a expressiva produção de teor autobiográfico de Fernando Sabino e a relevância que têm hoje as escritas de si, debruça-se sobre duas obras do autor mineiro, a autobiografia $O$ tabuleiro de damas (1988) e o livro de perfis Gente (1975), a fim de analisar a constituição do sujeito Fernando Sabino enquanto escritor a partir de sua relação com outros escritores.

Por meio dessas duas narrativas será investigada a hipótese de que, em sua escrita, Fernando Sabino textualiza elementos autobiográficos por meio de estratégias de ficcionalização que têm por resultado um texto híbrido, em que as fronteiras entre o real e o ficcional não podem ser delimitadas.
O tabuleiro de damas: uma autobiografia?

Segundo meu amigo jornalista Edwaldo Pacote, Otto Lara Resende costumava sustentar que escrever minha biografia era fácil, pois teria apenas duas frases, uma na primeira página e outra na última. Primeira: "ninguém sabe quem é Fernando Sabino." Última: "nem ele próprio.” (SABINO, 1999, p. 59)

O tabuleiro de damas distingue-se de outras obras escritas por Fernando Sabino anteriormente, como $O$ encontro marcado (1956) e $O$ menino no espelho (1982), devido ao pacto estabelecido com o leitor: o pacto autobiográfico. Ou seja, nesse livro existe a indicação por parte do autor de que nós, leitores, iremos encontrar, no texto, a voz do sujeito empírico, suas memórias e experiências de vida.

E realmente encontramos. No entanto, o leitor, que espera descobrir a história completa de um Fernando Sabino pleno, frustra-se, pois, na narrativa, até mesmo o autor demonstra querer saber quem de fato é. E essa descoberta é o que pretende alcançar por meio da escrita:

O que busco, escrevendo, é saber quem sou. Para que eu seja do meu tamanho, como todo mundo deve ser do seu: nem maior, nem menor. Quero dar o melhor de mim, ir ao extremo de mim mesmo. Não pretendo me exceder, mas também não quero ficar devendo. Esse é o meu objetivo na literatura e na vida (SABINO, 1999, p. 59-60).

Para Zygmunt Bauman, entretanto, a "identidade só nos é revelada como algo 
a ser inventado, e não descoberto; como alvo de um esforço, um objetivo" (2005, p. 21). Seguindo essa afirmação, a escrita de $O$ tabuleiro de damas não seria um modo de Fernando Sabino descobrir a si mesmo, mas, sim, de se autoconstruir narrativamente.

Bauman também discorre sobre a impossibilidade de se alcançar a identidade de modo homogêneo, uma vez que o mundo ao nosso redor está repartido em múltiplos fragmentos, fazendo, dessa maneira, com que transitemos por diversos meios, ideias e princípios que não estabelecem entre si nenhuma unidade aparente. Um escritor, por exemplo, pode ser professor, judeu, brasileiro, jornalista, etc., e todas essas identidades encontradas em uma única pessoa não necessariamente possuem relação entre si.

Em consonância com o pensamento de Bauman, a ideia de incompletude também é sugerida em $O$ tabuleiro de $d a$ mas, pois Fernando Sabino não atribui ao livro a categoria de autobiografia ou memórias, mas de "esboço autobiográfico", o que indica o caráter fragmentário, inacabado da identidade, impossível de ser abrangida de forma total em uma narrativa.

A tênue distinção entre realidade e fantasia é outra questão problematizada nessa obra. $\mathrm{O}$ título do livro refere-se a uma novela policial do autor - $O$ outro gume da faca-, em que um personagem diz que o tabuleiro de damas não é nem preto com quadrados brancos, nem branco com quadrados pretos, mas de outra cor, com quadrados pretos e brancos. A partir dessa metáfora, Fernando Sabino rompe com a noção de verdade e até mesmo com a ideia de que seja possível alcançá-la, a menos que essa busca se faça por meio da ficção: "uma verdade além da realidade, que só se alcança através da imaginação, da fantasia e do sonho" (SABINO, 1999, p. 61).

Logo no primeiro capítulo, Primeira vez, o autor declara não querer ter compromisso com a realidade, apenas com a verdade. "Mas o que é a verdade? Era o que Pilatos já perguntava ao próprio Cristo" (SABINO, 1999, p. 23). Assim, Fernando Sabino, em seu esboço autobiográfico, relativiza conceitos como realidade e verdade, e também questiona o próprio fazer literário:

\begin{abstract}
Num levantamento da minha vida literária, vejo nela que não tenho feito outra coisa senão me revelar, me expor, contar aquilo que vivi, testemunhei, pensei, aconteceu e chegou ao meu conhecimento - sempre através da mais torturante maneira de recriar a realidade. Deus sabe, por exemplo, o que me custa, na elaboração de despretensioso esboço autobiográfico como este, não entrar de cabeça na ficção adentro. São lembranças e considerações misturadas que afluem ao correr da pena (ou das teclas) sem muita ordem lógica (ou cronológica), cheias de parênteses mentais (1999, p. 60).
\end{abstract}

Como garantir, então, que o autor, no momento da escrita, não tenha ingressado na ficção? Até porque a recuperação das experiências vividas se dá pelo sujeito no presente, e "[...] essa autorreferência atual pode se mostrar um obstáculo para a captação fiel e a reprodução exata dos acontecimentos 
passados" (STAROBINSKI, [1970] 1974 apud ARFUCH, 2010, p. 54, grifo da autora). Desta forma:

A autobiografia, mesmo se limitada a uma pura narração, é sempre uma auto-interpretação, sendo o estilo o índice não só da relação entre aquele que escreve e seu próprio passado, mas também o do projeto de uma maneira de dar-se a conhecer ao outro, o que não impede o risco permanente do deslizamento da autobiografia para o campo ficcional, o seu revestir-se da mais livre invenção. Apesar do aval de sinceridade, o conteúdo da narração autobiográfica pode perder-se na ficção, sem que nenhuma marca decisiva revele, de modo absoluto, essa passagem, porquanto a qualidade original do estilo, ao privilegiar o ato de escrever, parece favorecer mais o caráter arbitrário da narração que a fidelidade estrita à reminiscência ou o caráter documental do narrado (MIRANDA, 1992, p. 30).

"A fidelidade estrita à reminiscência" faria da autobiografia somente um texto documental e, portanto, não literário. Porém, nas autobiografias em geral, e principalmente no caso das autobiografias de escritores, é ingênuo pensar que são textos produzidos com o objetivo último de retratar a história real de uma vida, tal como ela aconteceu. Essa pretensão desfaz-se, como vimos, pela própria impossibilidade de apreensão integral do passado. Além desse fator, todo autobiógrafo, no exercício de reconstruir o vivido a fim de revelá-lo ao leitor, o faz de modo que essa revelação se harmonize com a imagem idealizada de si. Em outras palavras, a recriação da realidade se dá em consonância com a autoimagem que o escritor deseja projetar.
A confluência entre biografia e invenção, como pudemos notar a partir dos exemplos expostos, surge, vez ou outra, em $O$ tabuleiro de damas, como objeto de reflexão. Fernando Sabino, na escrita de um livro declaradamente autobiográfico, parece contestar a questão referencial que a própria narrativa propõe.

Quando se refere, porém, a uma obra cujo pacto é romanesco, como o romance $O$ encontro marcado, o autor declara: " $O$ encontro marcado é a minha vida: é a súmula da minha experiência vital até aquele momento" (SABINO, 1985, p. 12). $\mathrm{E}$, de fato, identificamos diversas semelhanças entre as experiências vivenciadas pelo personagem Eduardo Marciano e aquelas de que temos conhecimento sobre Fernando Sabino por meio de entrevistas, excertos biográficos constantes nos paratextos e nas crônicas do autor. Muitas dessas experiências, contudo, não são narradas em $O$ tabuleiro de $d a$ mas. Outras, ainda, foram suprimidas pelo autor em edições posteriores. É o caso, por exemplo, do texto sobre Lygia Marina, esposa de Fernando Sabino no ano da publicação do livro, em 1988. Nas versões posteriores à separação do casal, em 1993, os parágrafos relacionados a Lygia desapareceram.

De acordo com Bloch, os ajustes que Fernando Sabino fez a cada nova edição de sua obra,

[...] dado o forte conteúdo autobiográfico de seus escritos, acabam por alterar, ao sabor das circunstâncias, o retrato que o leitor guardará dos fatos, e da realidade (2005, p. 123). 
Sabino estaria, dessa maneira, violando o pacto referencial proposto pelo livro. Mas não o pacto que estabeleceu consigo, pois, ao relativizar conceitos como o de realidade, o autor se mantém fiel ao seu compromisso literário em detrimento do documental. E também a própria definição de "esboço" sugere que o texto está "em construção", sendo passível de modificações.

Assim, o controle que o escritor exerce em sua autobiografia é equivalente ao que exerce sobre sua obra ficcional. As confissões "reveladas" no texto autobiográfico são produtos das escolhas do autor no presente da enunciação, e, como o passar do tempo provoca mudanças, com o escritor não é diferente. $\mathrm{O}$ autor, em períodos distintos, também poderá tornar-se outro, e, portanto, renovada será a sua perspectiva do lugar de fala, repercutindo, consequentemente, na história de sua vida. A autobiografia é, então, a narrativa de uma decisão do autobiógrafo no presente e não de uma vida completa e definitiva.

A declaração sobre Lygia era a única referência consistente, em $O$ tabuleiro de damas, sobre a vida amorosa do autor. Depois de sua exclusão, não encontramos citações a respeito de tal assunto, mesmo o escritor tendo sido casado por três vezes. Poucas também são as vezes em que o autor fala sobre a família e as experiências extraliterárias. Assim, diferentemente do subtítulo que figura na capa do livro - "trajetória do menino ao homem feito" -, o que encontramos na obra é a prevalência da autoimagem social de Fernando Sabino, uma vez que a narrativa valoriza mais a sua formação literária, suas leituras e influências, sua experiência como cineasta e editor e seu convívio com outros escritores do que a sua vida íntima de fato.

Há, contudo, no final da narrativa, uma espécie de compilação das pessoas mais importantes da vida pessoal do autor. O capítulo intitulado Quatro amigos versa sobre a intensa amizade entre Fernando Sabino, Hélio Pellegrino, Otto Lara Resende e Paulo Mendes Campos:

Tive outros amigos além deles. Entre meus parentes, há pessoas admiráveis, a quem quero bem: primos, genros, e noras, sobrinhos e até netos que me são caros. Meus irmãos, sem exceção, sempre foram maravilhosos para comigo: Luisa, com sua música; Conceição, com seu coração acolhedor; Gerson, com seu generoso dinamismo; Antônio, com sua sábia mansidão; Berenice, tão querida, que só deixou saudade. Os filhos, dos quais me orgulho - Eliana, Leonora, Pedro Domingos, Verônica, Bernardo e Mariana, fonte permanente de alegria no convívio. E Virgínia, viva na eternidade e no meu coração. Mas posso afirmar que, se eu não tivesse conseguido mais nada na vida, esta relação tão duradoura de quatro amigos já teria sido o melhor que eu poderia desejar neste mundo (SABINO, 1999, p. 204).

Essa ausência de elementos da biografia pessoal de Fernando Sabino em O tabuleiro de damas pode ser explicada pela intenção do autor em escrever uma autobiografia nos moldes de Itinerário de Pasárgada: uma autobiografia intelectual, portanto. A autobiografia de Manuel Bandeira "privilegia os episódios relevantes para a formação de poeta, 
'deixando na sombra' muitos outros que não se incluem no seu "ponto de mira" (ROCHA, 2009, p. 68).

Tal como o poeta, Fernando Sabino, em sua autobiografia literária, evidencia as experiências referentes à sua formação de escritor. O autor conta que a ideia de escrever $O$ tabuleiro de damas surgiu desde que incentivou Manuel Bandeira a escrever o Itinerário. E, como dizia não gostar de entrevistas, escrever um livro desse gênero seria uma forma de responder às perguntas que insistentemente lhe faziam:

Não gosto muito de entrevistas - embora a ideia deste livro, que me acompanha há anos, ao longo da minha vida literária, renove-se a cada entrevista que tenho dado (SABINO, 1999, p. 23, grifo nosso).

Por tais motivos, é comum encontrarmos mais elementos biográficos no romance $O$ encontro marcado e nas crônicas de Fernando Sabino do que em sua "autobiografia". Em geral, parece que "os gêneros autorreflexivos, que se supõem os mais referenciais, talvez sejam exatamente o contrário" (MAN, 1979 apud MOLLOY, 2003, p. 32).

Para Dante Moreira Leite (2007), é possível que na ficção o autor conte mais a respeito de si próprio do que no texto assumidamente autobiográfico. Como exemplo para sua hipótese, o teórico cita os livros ficcionais de Sartre. De acordo com Leite, na autobiografia de Simone de Beauvoir, A força da idade, podemos observar, pelos relatos da escritora, que o filósofo francês utilizou, "às vezes quase diretamente", suas experiências de vida como matéria para a sua obra de ficção. Em conformidade com esse pensamento encontra-se a seguinte frase de Oscar Wilde, lembrada por Leite: "[...] o homem quase nada nos diz quando fala em seu nome; dêem-lhe uma máscara, e ele dirá a verdade" (2007, p. 45).

De outro modo, Lejeune afirma que, independentemente das semelhanças encontradas nos textos ficcionais ou das discrepâncias descobertas na autobiografia, o que impera na narrativa é o contrato estabelecido entre o autor $\mathrm{e}$ o leitor:

A importância do contrato pode ser, aliás, comprovada pela própria atitude do leitor que é determinada por ele: se a identidade não for afirmada (caso da ficção), o leitor procurará estabelecer semelhanças, apesar do que diz o autor; se for afirmada (caso da autobiografia), a tendência será tentar buscar as diferenças (erros, deformações etc.). Diante de uma narrativa de aspecto autobiográfico, a tendência do leitor é, frequentemente, agir como um cão de caça, isto é, procurar as rupturas do contrato (qualquer que seja ele). Daí nasceu o mito do romance "mais verdadeiro" que a autobiografia: sempre se considera mais verdadeiro e mais profundo o que se descobriu através do texto, a despeito do autor (LEJEUNE, 2008, p. 26-27).

De modo diverso ao dos escritores que decidem se construir em textos referenciais, como as autobiografias e as memórias, para determinados autores:

[...] a confissão só é possível por figuras imaginadas, em que o autor projeta suas experiências e sua maneira de ver o mundo, ou, ao contrário, em que revela o que não quis ou não pôde ser (LEITE, 2007, p. 48).

Essa diferenciação nos modos de autorrepresentação narrativa ocorre na 
medida em que "[...] a confíssão direta pode ser frustrada, perdendo-se na superficialidade ou gratuidade" (LEITE, 2007, p. 48).

Fernando Sabino, por exemplo, com sua literatura notadamente autobiográfica, ao escrever sua autobiografia de forma declarada, cria diversas estratégias, como o título do livro e sua definição de esboço, a fim de tensionar os limites entre realidade e ficção. $\mathrm{E}$, na própria narrativa, discorre sobre a dificuldade em elaborar um texto que tem "compromisso com a realidade".

O próprio autor, no entanto, foi um incentivador de textos autobiográficos. Além de estimular Manuel Bandeira a escrever o Itinerário de Pasárgada, confessa-se orgulhoso por, junto com Otto Lara Resende, ter incentivado Pedro Nava a escrever suas memórias e ter sido o primeiro a editá-las:

Com isso a literatura brasileira se viu enriquecida de uma obra monumental (embora eu achasse que ele melhor faria se a concebesse em forma de romance, à feição de Proust - que me confessou haver lido seis vezes). Preferiu usar a realidade como matéria-prima, limitando a imaginação. Desceu até o fundo de si mesmo e acabou não conseguindo voltar (SABINO, 1999, p. 107).

$\mathrm{O}$ autor ressalta que preferiria se Pedro Nava tivesse escrito suas memórias em forma de romance. Desse modo, podemos observar que, mesmo a escrita de si tendo papel de destaque na obra de Fernando Sabino, há uma preocupação por parte do autor em evidenciar a ambiguidade na narrativa.
Quanto a essa questão, Klinger esclarece que:

[...] no depoimento de muitos escritores se vislumbra uma intenção de intensificar a ambiguidade, quando eles sustentam uma ideia de verdade na arte, ou seja, da superioridade do texto artístico sobre o referencial (2012, p. 35).

Nesse viés, Sabino esclarece:

Quando falo de mim mesmo e vou fundo na alma, sinto que estou matando a galinha dos ovos de ouro, desmotivando a minha literatura, acabando com a minha razão de escrever (1999, p. 24).

Existe, portanto, um limite para o que pode ser "revelado", e esse limite é estipulado pelo próprio escritor.

Em seu esboço autobiográfico, Fernando Sabino, com humor, parece falar de si mesmo abertamente: relata sua iniciação literária, suas primeiras leituras e influências, sua experiência de estrangeiro - como auxiliar no Escritório Comercial do Brasil em Nova Iorque e como adido cultural na embaixada em Londres -, o convívio com políticos e escritores e a impressão que eles lhe causam. Não hesita em mencionar nomes de pessoas "atestadamente reais" que fazem, por exemplo, parte do seu círculo de amigos, além de situações pelas quais passou com essas pessoas.

Todos esses relatos nos remetem a um discurso verídico, mas, ao mesmo tempo, artisticamente intencionado, pois, como nos esclarece Arfuch, a referencialidade não é o que mais importa nas narrativas atribuídas a personagens realmente existentes, e sim as estratégias ficcionais de autorrepresentação: 
Não tanto a "verdade" do ocorrido, mas sua construção narrativa, os modos de (se) nomear no relato, o vaivém da vivência ou da lembrança, o ponto do olhar, o que se deixa na sombra; em última instância, que história (qual delas) alguém conta de si mesmo ou de outro eu. E é essa qualidade autorreflexiva, esse caminho de narração, que será, afinal de contas, significante (2010, p. 73, grifo do autor).

\section{As estratégias de autorrepresentação de Fernando Sabino}

Uma estratégia notadamente utilizada pelo autor em $O$ tabuleiro de damas é o deslocamento do foco da narração para a história de outras personalidades. No decorrer dos trinta capítulos que compõem seu esboço autobiográfico, Sabino narra os encontros com diversos escritores e a importância que muitos deles tiveram para a sua formação. As histórias que o autor escolheu contar sobre sua vivência com esses escritores são geralmente pautadas pela leveza e pelo humor. Em uma delas, descreve a participação que teve como jurado no concurso de Miss Brasil, em 1954, ao lado de outros escritores. Entre eles, Manuel Bandeira:
A propósito, me lembro que, hospedado no Hotel Quintandinha onde se realizava o con- curso, às tantas Manuel Bandeira me con- vocou ao seu quarto. E me confidenciou ter ouvido dizer que algumas daquelas lindas concorrentes usava algo chamado "falsies". - Que vem a ser isso? - perguntou, apre- ensivo.

Ao saber que se tratava de seios postiços, considerou se, por via das dúvidas, não seria o caso de fazer com que as candidatas se apresentassem sem sutiã. E ante meu pasmo, esclareceu, em tom sério:

- Só para nós, jurados, é claro (SABINO, 1999, p. 128).

Os trechos que se seguem tratam da convivência entre Fernando Sabino e Carlos Drummond de Andrade, Pedro Nava, Jayme Ovalle e Vinicius de Moraes, respectivamente:

Carlos e eu nos tornamos muito amigos. Eu gostava de lhe passar trotes pelo telefone, e ele sabia se vingar à altura (1999, p. 104).

Pedro Nava e eu também nos víamos com frequência. E muitas vezes eu me valia da condição de cliente para ir ao seu consultório, em geral ao fim da tarde, o que redundava em horas de conversa. Segundo sustentava ele, o cliente que não sai do consultório melhor do que entrou não devia pagar consulta.

Não era o meu caso: nunca me cobrou, sempre saí melhor do que entrei. E nos divertimos com a sua brilhante atuação como ator no filme que fiz sobre ele (1999, p. 106).

Ovalle tinha uma dimensão mágica, com pleno domínio da arte de ir até onde a imaginação alcança, sem ficar louco. Só conheci outro com esse poder: Hélio Pellegrino. Em compensação, Ovalle não conseguia responder uma carta (eu respondia para ele), mal sabia usar o telefone. Não parecia mesmo ser deste mundo.

Era íntimo dos passarinhos. Houve um tempo em que andou noivo de uma pomba. Costumava dizer que Deus é poeta - basta identificar suas obras poéticas na natureza. Só que Deus fez muito rascunho: o hipopótamo, a girafa, o canguru, o rinoceronte são rascunhos. Quando Deus chegou à perfeição do cavalo, a obra estava pronta. E passarinho é um soneto, a Sua obra mais perfeita (1999, p. 113).

Vinicius [...] Viajou para os Estados Unidos no mesmo avião, e resolveu se dar por per- 
dido comigo em Nova York, durante uns dois meses. Levamos quatro dias para chegar, numa viagem cheia de peripécias, com memorável noitada em Ciudad Trujillo.

Conviver com Vinicius era um eterno festim, como no verso de Rimbaud (1999, p. 112).

A citação do verso de Rimbaud no fragmento sobre Vinicius de Moraes evidencia uma das leituras de Fernando Sabino. A propósito, ao longo de $O$ tabuleiro de damas, observamos, embora de modo espontâneo, diversas referências às leituras feitas por Sabino. Tal aspecto demonstra sua vasta experiência enquanto leitor e conhecedor da literatura mundial.

Diversas são as pessoas biografadas em $O$ tabuleiro de damas, além do próprio autor. Uma, inclusive, mereceu destaque, com capítulo intitulado por seu nome, Clarice. Nesse capítulo, Fernando Sabino narra seu encontro com Clarice Lispector e a intensa amizade que os uniu "ante o enigma que o futuro reservava" para o destino dos dois jovens como escritores. Sabino manifesta, de modo nítido, seu encanto pela escritora:

Era desconcertante certa aura de pureza, de primitiva inocência que dela se irradiava. Um dia, por exemplo, falávamos em Proust e ela me perguntou se era verdade que sua personagem Albertine na vida real vinha a ser um homem. Mostrou-se espantada ao imaginar - e pela primeira vez! - que um homem pudesse ter relação de amor com outro homem.

Reação surpreendente de que também me recordo foi a sua, quando eu lhe disse que mais um filho meu estava a caminho.

- Mais um? - exclamou ela:-Será que você não para? Pedi-lhe desculpas, dizendo que não me levasse a mal - acontecia nas melhores famílias (1999, p. 116).
A aura de pureza que Fernando Sabino atribui a Clarice é uma das estratégias utilizadas pelo autor para recriar a realidade. O escritor demonstra exercitar, tanto na literatura quanto na vida, uma espécie de olhar infantil. Desse modo, a visão que expressa das coisas e das pessoas, no texto, é frequentemente aprazível.

O olhar de menino, em conjunto com o otimismo, a simplicidade e o humor, perfaz a imagem que o autobiógrafo constrói de si. Essas características conferidas ao escritor Fernando Sabino em sua "autobiografia" também são notadas nas entrevistas e, guardadas as proporções, em toda a obra do autor. Assim, a validação de uma imagem autoral "existe como impulso que governa o projeto autobiográfico" (MOLLOY, 2003, p. 22) de Fernando Sabino.

Como $O$ tabuleiro de damas privilegia a figura do escritor e não do autor enquanto pessoa, a maioria das lembranças, ainda que da infância e juventude, são de episódios referentes à iniciação literária:

Ali pelos onze, doze anos, já na fase de ler romances policiais, passei a colaborar com alguns mestres do gênero: Edgar Wallace, principalmente, mas também Sax Rommer, SS. Van Dine... Então criei meu próprio detetive: Fred Smith, 22 anos de idade, alto, moreno, simpático, que "trafalgava" por Londres com sua bengala de castão de ouro. Algumas de minhas histórias, graças ao meu irmão Gerson, foram publicadas numa revista da polícia mineira chamada Argus. Estreei na literatura sob os auspícios da polícia (1999, p. 30). 
Há, porém, em alguns momentos da narrativa, reminiscências do convívio com a família:

Já em se tratando da minha vivência, propriamente, tenho na lembrança até hoje vários princípios que gostaria de praticar: os que meu pai, um filósofo à sua maneira, costumava ensinar aos filhos. Enquanto Dona Odete, minha mãe, era a doçura personificada, nos cobrindo de carinho, Seu Domingos nos dispensava docemente outra espécie de desvelo. Homem simples, de poucas ambições, ele era, apesar disso, ou por causa disso, de extremo bom senso. [...] Ele vivia dizendo: "O que não tem solução, solucionado está." Ou então: "As coisas são como são e não como deviam ser." O melhor, talvez que me lembre, foi o que me disse um dia ao me encontrar entregue à aflição de espírito: - Meu filho, tudo no fim dá certo. Se não deu, é porque ainda não chegou ao fim (1999, p. 75-76).

A partir do trecho citado e de outros contidos na obra referentes à família do autor, principalmente nas lições transmitidas pelo pai, podemos perceber que:

[...] o passado evocado molda-se por uma autoimagem sustentada no presente - a imagem que 0 autobiógrafo tem, aquela que ele [...] deseja projetar ou aquela que o público pede (MOLLOY, 2003, p. 22).

Ou seja, Fernando Sabino, em O tabuleiro de damas, elabora seu passado em conformidade com sua imagem de figura pública, a do escritor bem-humorado, otimista e simples. Tal autocaracterização, construída pelo autor, teria origem nos ensinamentos familiares.

Sabino, em sua autobiografia, além das características abordadas que remetem simultaneamente à figura pessoal $\mathrm{e}$ à pública, inscreve-se como um escritor sem preocupação com rótulos literários e disposto a desempenhar com qualidade o papel que escolheu para si na literatura:

Para certas pessoas, não sendo romance, não vale. Lembro-me que um dia Guimarães Rosa me telefonou e perguntou o que eu estava fazendo. Eu disse que estava tentando escrever uma peça de teatro. E ele, meio paternal:

- Não faça biscoitos, faça pirâmides.

Fiquei algum tempo encafifado com aquilo, sem saber se a obra literária se impunha também pelo gênero e pelo tamanho, além da qualidade. [...] Ninguém é obrigado a ser Tolstói na vida [...] Nem julgado por ser biscoiteiro ou faraó (1999, p. 49).

Nas entrevistas, o discurso é semelhante:

Quando li Dostoiévski pensei em desistir, porque ele já tinha escrito tudo o que eu queria escrever. Você percebe então que tem alguma coisa a dizer que é pequenina, é um biscoitinho, mas que vale tanto quanto a pirâmide dos outros, porque é sua. É a sua visão de mundo (SABINO, 1985, p. 23).

Por meio de algumas entrevistas de Fernando Sabino, é possível perceber que o autor se mostrava preocupado em produzir uma literatura que dialogasse com os leitores da sociedade contemporânea: "Não pretendo praticar uma literatura só para mim, e só para uma meia dúzia, e sim para o maior número possível de pessoas" (SABINO, 2002, p. 313). Talvez por esse motivo, Sabino tenha optado pelos "biscoitos" para compor a maior parte de sua obra. A crônica seria, então, uma das maneiras encontradas por Sabino para aliar a expressão literária à comunicação do nosso tempo. 
Em suas crônicas, verificamos diversas semelhanças entre os acontecimentos narrados e os vivenciados pelo autor. Essas semelhanças são reiteradas em $O$ tabuleiro de damas, no qual, em diversas partes da narrativa, há um asterisco que indica, ao final da página, em que crônica aquela história foi contada. O que pode ser interpretado como uma estratégia de legitimar a realidade nas crônicas, ou ao contrário, de ficcionalizar os relatos da autobiografia, ou, ainda, evidenciar o trânsito entre experiência pessoal e criação literária.

Além da transição entre vida e obra, há também, na narrativa, a transição entre gêneros literários, já que os capítulos de $O$ tabuleiro de damas podem ser lidos individualmente como se fossem crônicas. Não há uma linearidade narrativa que subordine um capítulo a outro, iniciada com as primeiras lembranças até o desenvolvimento do sujeito, como geralmente se espera dos gêneros que têm como base a vida.

Mas, em alguns momentos da narrativa, como verificamos, existe uma desestabilização da leitura referencial, provocada por declarações e dúvidas do autor quanto à (im)possibilidade da escrita autobiográfica e, também, da apreensão total do sujeito. Essas (im) possibilidades são sugeridas no trecho citado que dá início ao presente trabalho: "ninguém sabe quem é Fernando Sabino, [...] nem ele próprio". Assim, O tabuleiro de damas, livro declaradamente autobiográfico, apresenta também traços do texto autoficcional ao contribuir para a construção do mito do escritor.

A reiteração de experiências e de cenas na obra do escritor mineiro não se estabelece apenas entre as crônicas e $O$ tabuleiro de damas, mas em diversos textos e entrevistas do autor, o que caracteriza uma marca de estilo. As cenas de leitura de Fernando Sabino em $O$ tabuleiro de damas, por exemplo, são semelhantes às do protagonista do romance $O$ encontro marcado.

\section{A cena de leitura}

Sylvia Molloy, em sua pesquisa sobre a escrita autobiográfica na América hispânica, evidencia a cena de leitura como uma estratégia do autobiógrafo - neste caso, também escritor -, para confirmar uma vocação literária revelada ainda na mocidade:

A importância dada à cena de leitura na juventude do autobiógrafo pode ter sido originalmente feita como um truque realista, destinado a dar verossimilhança (e, em retrospecto, uma pequena porção de glória precoce) a uma história de escritor. Na verdade, funciona como uma estratégia autorreflexiva que confirma a natureza textual do exercício autobiográfico, lembrando-nos do livro por trás dele (2003, p. 38).

O livro "por trás" do autobiógrafo suas primeiras leituras e influências literárias - nunca é gratuito. Ou seja, a exposição, na autobiografia, dos autores que contribuíram para a formação literária do autobiógrafo será feita sempre de modo a valorizar sua imagem como 
escritor; será, portanto, literariamente intencionada:

[...] o autobiógrafo não poderá ser pego em falta, culturalmente desarmado, um intelectual simplório aos olhos dos outros, por isso, a ostensiva preferência pelos clássicos (MOLLOY, 2003, p. 40).

Assim ocorre na evocação das leituras preponderantes para a formação do escritor Fernando Sabino. O autor relata o encontro com Guilhermino César, seu primeiro orientador literário. Guilhermino apresenta ao jovem Fernando nada menos que três escritores pertencentes ao cânone da literatura universal:

Um dia, por insistência minha, meu irmão me apresentou a Guilhermino César, seu conhecido, e que tinha publicado um livro na Editora José Olympio - o auge da glória, o Olimpo dos escritores.

Levei meus contos à casa do Guilhermino num domingo. Chovia muito naquela manhã, e três coisas me impressionaram: primeiro, Guilhermino me disse que ter sido premiado não era garantia de qualidade; segundo, depois de ler os contos, apanhou na estante três contistas para me emprestar Maupassant, Merimée e Flaubert; terceiro, ele disse "merda", porque a água da chuva havia inundado seu escritório. Eu não podia acreditar que escritor também falasse palavrão (SABINO, 1999, p. 33).

Interessante perceber que, em $O$ tabuleiro de damas, Fernando Sabino relaciona a cena de leitura a um mentor. Aspecto verificado com frequência, por Molloy (2003, p. 35), nas autobiografias hispano-americanas.

Podemos observar, também, que a cena representativa da iniciação literária de Fernando Sabino é semelhante à do protagonista de $O$ encontro marcado,
Eduardo Marciano. No romance, entretanto, quem estabelece o contato entre o protagonista e seu mentor é o pai de Eduardo:

Seu Marciano mandou que procurasse Toledo, um amigo que era escritor.

Toledo acabara de publicar um romance em editora do Rio, seu nome era conhecido nos meios literários. [...]

Eduardo foi à casa do romancista, levando seus contos numa pasta, debaixo do braço. [...] - Você quer ser romancista, não é? - e Toledo o reteve, quando se despedia: - Pois então leia isso... $\mathrm{E}$ isso... $\mathrm{E}$ isso.

Emprestou-lhe três livros de contos em Francês: Merimée, Flaubert e Maupassant (SABINO, 2010, p. 55).

Além dos autores franceses, Fernando e Eduardo têm em comum o deslumbramento que sentiram, ainda na juventude, por outro escritor clássico, Dostoiévski:

[...] Quando descobri Dostoiévski, por pouco não desisti: tudo que eu queria escrever ele já havia escrito (1999, p. 42).

[...] Leu os romancistas brasileiros, alguns franceses, esqueceu tudo em favor de Dostoiévski. Sentia-se encarnado em Raskolnikoff, chegou a pensar em cometer o crime perfeito (2010, p. 65).

Aliás, tanto $O$ tabuleiro de damas quanto $O$ encontro marcado são obras recheadas por citações e referências a livros e autores. Há inclusive, no final de $O$ encontro marcado, um anexo intitulado "Citações e referências em $O$ encontro marcado apresentadas pelo autor", no qual Fernando Sabino faz breves comentários sobre a intertextualidade presente no romance. Tais referências demonstram que a construção do escritor ocorreu a partir de sua relação com outras leituras e escritores. 
Ao investigar o passado, Fernando Sabino, em seu esboço autobiográfico, narra a descoberta de uma lista escrita há 35 anos de distância do presente da enunciação:

Há pouco tempo encontrei a seguinte anotação minha, aos trinta anos, com uma lista de escritores que me inspiravam simpatia e antipatia:

Antipatia: Goethe, Montaigne, Flaubert, Turgueniev, Gide, Valéri, Claudel, Mauriac, Papini, D'Anunzio, Sartre, Camus, Huxley, Joyce, Proust, Longfellow, Kafka, Alberti, Eliot, Rimbaud, Breton, Jarry, Faulkner, Shaw, Chesterton.

Simpatia: Rabelais, Cervantes, Molière, Donne, Blake, Lautréamont, Cocteau, Apollinaire, Saint-Exupery, Bernanos, Hemingway, Fitzgerald, Henry James, Eric Gill, Herbert Read, Ruskin, William Morris, Milosz, Fernando Pessoa, Lawrence, Pirandelo, Ezra Pound, Stendhal, Verlaine, Antonin Artaud, Mark Twain, Svevo, Dostoievski, Conrad, Tolstoi (1999, p. 44).

A descoberta dessa lista de escritores, além de colaborar para uma impressão de resgate do passado, confirma a insistência do autor na cena de leitura. De acordo com Molloy,

[...] seria estranho se não fosse assim, pois, no momento em que ele [o autor] decide explorar o passado, verá sem dúvida com bons olhos qualquer experiência de sua juventude que possa ser interpretada como a promessa de uma futura vocação e, por isso, insistirá nela (2003, p. 37-38).

A partir dos exemplos expostos, observamos que "o autobiógrafo [...] vive no livro que escreve e se refere incansavelmente a outros livros" (MOLLOY, 2003, p. 32). Assim sendo, concluímos que, dentre outras histórias de vida possíveis, a escolhida pelo autor para ser contada foi a vida literária. Talvez porque o Fernando Sabino "real" só esteja disponível narrativamente, no lugar que a imaginação alcança, e, mesmo quando surpreendido fora do livro, parece um personagem dele.

Fernando Sabino em alguns capítulos de $O$ tabuleiro de damas, como vimos, dá destaque a outros escritores. Dessa maneira, o autor desvia o foco narrativo do que deveria ser a história de sua vida para evidenciar características de outras personalidades. Em outro livro do autor, Gente, a proposta é, justamente, retratar perfis de diversos artistas, Fernando Sabino, muitas vezes, faz o contrário. $\mathrm{O}$ autor acaba mudando a perspectiva e enfocando a si próprio, como veremos a seguir.

\section{Fernando Sabino e sua gente}

Os textos que compõem o livro Gente são pequenos perfis escritos por Fernando Sabino de personalidades das áreas mais variadas: literatura, música, esporte, dramaturgia, etc. Esses perfis, a princípio biográficos, misturam-se com evocações e impressões de quem os escreve. Assim, Fernando Sabino como biógrafo não deixa de ser autobiógrafo, pois, em todos esses textos, é possível perceber sua forte presença autoral; e, além desse aspecto, a recriação literária do outro se dá, visivelmente, a partir da percepção do autor. 
Diferentemente do que, via de regra, ocorre em textos biográficos, Fernando Sabino não se anula nos perfis que escreve. Embora saibamos que, mesmo em textos biográficos, é difícil o autor apagar-se por completo, geralmente é desta forma que se costuma escrever tal gênero: focalizando preferencialmente $-\mathrm{e}$, às vezes, exclusivamente - $\mathrm{o}$ biografado.

Fernando Sabino, ao contrário, parece estar sempre propenso a mostrar a si próprio, ainda que o compromisso do texto seja com a exibição do outro, como é o caso desses perfis. Nas palavras de Betella:

Fernando parece não segurar o entusiasmo pela participação na narrativa, tomando a palavra sem o anteparo de um narrador, melhor dizendo, sem a criação de um sujeito, personificado ou não. A forma de organização do discurso não tem, aparentemente, nenhuma estratégia para encobrir, disfarçar ou obstruir a primeira pessoa, no caso, real (2005, p. 130).

Esse efeito de identificação da voz narrativa à voz do próprio autor Fernando Sabino é provocado pelo fato de as minibiografias serem concebidas no estilo de crônica, gênero caracterizado pelo uso da primeira pessoa e pelo tom informal. Gênero também predominante na obra de Fernando Sabino e no qual ele se destaca como um dos mestres no Brasil. Na maioria das crônicas do autor mineiro, observamos o pacto identitário entre autor, narrador e personagem.

O mesmo verifica-se na narrativa dos perfis: o autor Fernando Sabino posiciona-se simultaneamente como narrador e personagem. Ao ficcionalizar pessoas reais e seu encontro com elas, ficcionaliza a si mesmo. O autor apresenta, assim, todo um grupo de personalidades artísticas que fizeram parte de sua geração e que, de certa forma, colaboraram para o escritor que ele se tornou. Para Otto Lara Resende,

Gente contribui para descodificar e até complementar a mensagem de $O$ encontro marcado, que, tanto quanto pessoal, pode ser também de uma geração (1996 apud SABINO, 1996, p. 10).

Todos os encontros relatados em Gente transmitem uma imagem do biografado - e também do narrador - humanizada, como a de pessoas comuns.

A crônica, como assinala Antonio Candido, também apresenta esse caráter humanizador:

Por meio dos assuntos, da composição aparentemente solta, do ar de coisa sem necessidade que costuma assumir, ela se ajusta à sensibilidade de todo o dia. Principalmente porque elabora uma linguagem que fala de perto ao nosso modo de ser mais natural. Na sua despretensão, humaniza; e esta humanização lhe permite, como compensação sorrateira, recuperar com a outra mão uma certa profundidade de significado e um certo acabamento de forma, que de repente podem fazer dela uma inesperada embora discreta candidata à perfeição $(1979$, p. 5).

Assim, podemos inferir que Fernando Sabino vale-se de sua experiência como cronista para a produção de seus textos narrativos mais longos e de maior porte. A leveza, a simplicidade, o humor e o próprio relato pessoal característicos da crônica são encontrados, como apontamos, em toda a obra de Sabino. 
Desse modo, no perfil Duas mãos e o sentimento do mundo, a ideia da figura do pianista como um "sujeito sério, compenetrado, em geral de casaca", que não "olha para a gente, não fala nada, não sorri”, é desconstruída pelo autor, que apresenta o grande pianista Arthur Moreira Lima como um "cara alegre, engraçado, descontraído e até mesmo desengonçado" (SABINO, 1996, p. 291). Tal estratégia de humanização transforma, pela perspectiva de Sabino, um dos maiores pianistas do mundo em menino:

O que eu acho é que este garoto de 36 anos que tenho hoje à minha frente, simpático e comunicativo, tomando uísque na minha casa e quase que só falando em futebol (a todo momento tenho de interrompê-lo e levar o assunto de novo para a música) só deve se tornar mesmo um pianista quando tem diante de si um piano. Coisa, aliás, que ele confessa detestar, quando não está trabalhando: - Casa que tem piano é fogo: não me dá sossego. Já bastam os pianos que a gente tem de enfrentar por aí nos concertos, cada um pior que o outro. Há pouco tempo num concerto aqui no Brasil, me disseram: esse piano é respeitável, Rubinstein já tocou nele. E eu comigo: pois então é respeitável de tão velho, deve ter mais de cinco anos. Um piano, para ser bom mesmo, não pode ter mais de dois (SABINO, 1996, p. 191-192).

A narrativa desses pequenos instantes biográficos é, por vezes, como podemos observar no fragmento citado, entrecruzada pela voz da personalidade biografada. Isso porque Fernando Sabino, para a composição dos perfis, entrevistou muitos daqueles que seriam personagens em Gente, a fim de ter material para a sua escrita. A transcrição dessas falas, entretanto, pode causar a impressão de estarmos diante de um texto jornalístico e não literário. Ao mesmo tempo, é possível perceber que a entrevista não está toda ali, mas apenas algumas declarações selecionadas pelo próprio Fernando Sabino e que contribuem para compor a imagem do biografado que o autor deseja transmitir.

Assim como no perfil Duas mãos e o sentimento do mundo, no qual Fernando Sabino compara Arthur Moreira Lima a um "meninão", também em A criança que existe em nós, Maria Clara Machado parece levar sempre consigo a criança que um dia foi. As declarações da dramaturga, portanto, são inseridas na narrativa a fim de atestar essa imagem de menina:

- Quando escrevo minhas peças, não penso em crianças. Penso nas impressões mais vivas da minha infância.

Seus olhos brilham - os mesmos olhos da menina que eu via passeando na Praça da Liberdade, em Belo Horizonte:

- Eu me dirijo a uma idade que não é nem das crianças nem dos adultos, fora do tempo, aquela idade ideal que todos nós deveríamos ter (SABINO, 1996, p. 122).

Ao mesmo tempo em que escreve sobre Maria Clara Machado, o autor escreve sobre si mesmo, ao relembrar a juventude de ambos na cidade de Belo Horizonte. A narrativa, inicialmente biográfica e jornalística, adquire um tom nostálgico semelhante ao das memórias:

Conversamos durante duas horas, sem sequer iniciar a entrevista que eu pretendia fazer com ela. Somos dois velhos amigos que se reencontram, na lembrança dos tempos de infância vividos na cidade em que nascemos. Aos poucos, fomos nos transformando naquilo que ela busca atingir com sua arte: a criança que existe em nós (SABINO, 1996, p. 124, grifo nosso). 
A imagem da escritora, contudo, permanece em destaque na narrativa e, mais do que isso, figura como um reflexo da imagem que o próprio autor construiu de si.

A reevocação da infância e da juventude do autor aparece também em outros perfis, principalmente nas biografias em que a personalidade retratada fez parte da sua mocidade, como é o caso dos perfis de Paulo Mendes Campos e Ivo Pitanguy. Em Domingo azul do bar, Sabino relata como conheceu Paulo Mendes Campos:

A primeira vez que o vi, ele já era um rapa-
zinho, cabelo caído na testa - e já o copo na
mão: o Paulinho, "perdido na dramaticidade
existencial da poesia". E eu, outro rapazi-
nho, perdido na dramaticidade existencial
da prosa. Numa festa na casa do cônsul
inglês em Belo Horizonte, eu havia buscado
com a namorada o recanto de uma varanda
deserta, para ver se lhe furtava um beijo.
E dei com ele ali, copo na mão, sozinho, a
conversar consigo mesmo e atrapalhar-nos
com a sua presença indiscreta. Tive de adiar
o beijo. Mais tarde nosso primeiro encontro se faria em termos já literários, aos dezesseis ou dezessete anos, no ardor de uma conversa em que discutíamos se Dom Quixote era escrito em prosa ou em verso. E nos tornamos amigos para sempre (SABINO, 1996, p. 242).

O perfil de Paulo Mendes Campos, de maneira semelhante aos demais que integram Gente, entrelaça a narrativa do autor com a fala do biografado. Essas falas são retiradas tanto das entrevistas quanto, no caso dos escritores, da sua obra literária. Abaixo um exemplo desse entrelaçamento encontrado na narrativa sobre Campos:
Temos em comum o gosto humilde da alegria, a partir do hábito de nos tratarmos por apelidos. Para ele sou o De Lesseps (Ferdinand de Lesseps), ou o Bacharel da Cananéia ("Cana", na intimidade); para mim, ele se chama Nicodemus, Nicanor. Nicomedes ou Nicobar, conforme a ocasião.

Tenho flores silvestres. Faço versos nas ocasiões. Estudei o que dava para passar. Mas nasci para dançar (SABINO, 1996, p. 244-245).

No perfil de Ivo Pitanguy, Doutor 48 horas por dia, apenas descobrimos a identidade do biografado na última linha do texto. Essa estratégia, de não anunciar de imediato quem é a personalidade em questão, ocorre na maioria dos perfis. Fernando Sabino inicia os textos descrevendo alguém que, em um primeiro momento, não sabemos quem é. As pistas deixadas na narrativa, entretanto, nos permitem deduzir, em alguns casos, a identidade do biografado antes de sua revelação pelo narrador. Mas, em Doutor 48 horas por dia, a identidade de Pitanguy pode ser confundida, em alguns momentos, com a de Hélio Pellegrino, pois, tal como o cirurgião plástico, Pellegrino também era estudante de medicina e amigo de Fernando Sabino desde a infância.

O cenário desenhado no perfil de Pitanguy é o da cidade de Belo Horizonte na década de 1940, o mesmo da juventude do protagonista Eduardo Marciano em $O$ encontro marcado: 
Eu me lembro dele desde a infância - no tempo em que as quadrilhas de meninos em Belo Horizonte guerreavam a pedradas num lugar chamado buracão, onde é hoje o Minas Tênis Club. Juntos disputamos as mesmas namoradas, no footing da Praça da Liberdade e conhecemos as primeiras mulheres, no trottoir da Praça da Estação. Juntos fomos escoteiros, andamos de bicicleta, praticamos natação, viajamos para Uberaba, Uberlândia, Caxambu, São Paulo, Rio, disputando campeonatos (SABINO, 1996, p. 95).

A história de vida do biografado é, então, misturada às lembranças, experiências e percepções do narrador:

Já era estudante de Medicina e a vocação herdada do pai se manifestava em toda a sua pujança. Quando me levou à sala de anatomia da Faculdade, era de se ver o prazer meio sádico com que ele abria, para me mostrar, umas caixas enormes cheias de cadáveres mergulhados em formol. Passei três dias sem comer.

E ainda: caímos dos mesmos cavalos, prestando serviço militar no CPOR. Tomamos um de nossos primeiros pileques (de gim, num botequim da Rua São José) e me lembro que ele quis dar uma gravata no motorista do táxi que nos transportou até o hotel. No dia seguinte fomos curar nossa ressaca na ressaca maior do Lido, enfrentando temerariamente as ondas gigantescas, como se fôssemos imortais (SABINO, 1996, p. 95-96).

Não sabemos, todavia, até que ponto o papel da memória, na narrativa, é utilizado para contar o que de fato aconteceu. É possível que muitas das rememorações do autor sejam baseadas somente em situações ficcionais. Em algumas passagens, inclusive, nos deparamos claramente com um discurso ficcional, como quando o autor diz: "Passei três dias sem comer". A exposição exagerada de tal episódio confere ao texto um tom de humor característico da prosa do autor mineiro. A narrativa assume, portanto, um caráter híbrido, ao transitar livremente entre a biografia e a invenção literária.

Ainda no mesmo perfil, depois de todas as recriações da memória, o biografado tem, enfim, sua identidade revelada:

Tudo considerado, posso dizer que o Helcius, como então ele era chamado, é meu amigo desde que nos entendemos por gente. Ivo Helcius Jardim de Campos Pitanguy - Dr. Ivo Pitanguy, nome que se tornou uma legenda (SABINO, 1996, p. 96).

Já em O menestrel de nosso tempo, as características apresentadas não deixam dúvidas quanto à identidade do biografado, e logo reconhecemos a figura de Vinicius de Moraes:

Outro dia ele me telefonou de Porto Alegre. Como vão as coisas? E aqueles longos silêncios que me obrigam a falar sem parar, dando notícias, inventando assunto. O interlocutor em geral não sabe que ele está falando de dentro de uma banheira, onde permanece horas, copinho de uísque à mão, papel e lápis para qualquer eventualidade, e o telefone para saber dos amigos como vão as coisas. Telefona de onde estiver: de São Paulo, Recife, Lisboa, Paris. Telefonava de Los Angeles para Nova York, onde eu morava, e me dava aflição a distância entre as duas cidades, implicando uma conta de interurbano catastrófica para ele naquela época: Que é que você manda? Está precisando de alguma informação? Algum recado urgente?

E ele, com a voz descansada:

- Não, é só pra saber como vão as coisas (SABINO, 1996, p. 19-20, grifo nosso).

Os relatos divertidos que compõem $o$ perfil de Vinicius de Moraes contribuem para a imagem que temos do poeta como alguém "imperturbável". Essa ca- 
racterística, por conseguinte, pode ser associada à despreocupação própria da idade infantil. Desta forma, Sabino, ao recriar um encontro entre ele e Vinicius de Moraes, o faz de modo espelhado:

Trinta anos de convivência! Um dia desses marcamos um encontro. Escolhemos um bar pouco frequentado, onde pudéssemos conversar calmamente. $\mathrm{E}$ de súbito, solenizados diante de nosso uísque, em silêncio até ali, nos olhamos e comecamos a rir: engracado esse nosso encontro para conversar. Conversar o quê? Já não está tudo conversado? Pois então vamos embora, não é isso mesmo? E começamos a rir feito dois meninos, sem perceber que estávamos exercendo o simples ritual da amizade além das palavras (SABINO, 1996, p. 21, grifo nosso).

Não fica claro, na narrativa, quem proferiu as perguntas. Consta apenas que os escritores se olharam simultaneamente depois de um período em silêncio, e as atitudes seguintes também parecem ter sido simultâneas. É como se um escritor estivesse refletido no outro e, nós, leitores, já não sabemos quem é um e quem é o outro, talvez porque sejam idênticos em sua meninice. Afinal, todos se transformam em menino nas histórias de Fernando Sabino.

Desse modo, observamos que, em se tratando da produção de Fernando Sabino, mesmo os textos que objetivam evidenciar a imagem do outro são utilizados pelo autor como um veículo para a construção de si próprio, pois

[...] não estamos mais em um regime discursivo em que determinado número de normas se impõe aos escritores; entramos num universo em que o escritor deve constantemente legitimar seu processo criativo elaborando uma imagem de autor à medida de sua obra (MAINGUENEAU, 2010, p. 152).
Então, ao longo das leituras das crônicas que compõem o livro, concluímos que "mais do que o autor fala dessa gente, essa gente fala do autor" (RESENDE, 1996 apud SABINO, 1996, p. 10). E, de modo especial, observamos essa marca de estilo no perfil "Improviso do amigo morto", sobre Mário de Andrade.

A narrativa sobre Mário é iniciada dando destaque às correspondências que o autor recebia, em sua casa, no famoso endereço da Rua Lopes Chaves, número 546, em São Paulo. Nesse endereço, Mário de Andrade recebia cartas de escritores, artistas e amigos de todo o país; sua incontestável qualidade de missivista também foi responsável pela amizade que criou com Fernando Sabino.

Sabino, no auge de sua juventude e aspiração literária, envia a Mário seu primeiro livro, Os grilos não cantam mais. E recebe, para sua surpresa e satisfação, uma carta do missivista. No perfil, Sabino narra a impressão de tal momento:

Uma delas certo dia me chegou às mãos em Belo Horizonte. Mãos pressurosas em rasgar avidamente o envelope, na excitação dos dezoito anos, tão logo dei com o nome do remetente e o famoso endereço.

Passei a ser respeitado em casa. [...] Nenhum estímulo poderia ser maior para um estreante na literatura que aquelas palavras de aguda compreensão, apontando qualidades e perdoando defeitos, que denunciava com precisão (SABINO, 1996, p. 97-98).

A narrativa prossegue, mesclando recordações do autor com fragmentos de cartas e poemas de Mário de Andrade. Sabino descreve as dúvidas que o atormentavam na juventude, tanto na literatura quanto na vida, e a paciência 
de Mário em responder a tamanhas inquietações:

Eu lhe confiava as minhas dúvidas e preocupações literárias, com o ardor dos que querem vencer a todo custo: o problema da sinceridade do artista, a importância ou desimportância do sucesso, a necessidade de escrever e ao mesmo tempo ganhar a vida, o aprimoramento do estilo, a opção entre a arte social e a arte-pela-arte, e outros temas em moda na época. Com sua paciência apostolar, ele me respondia longa e minuciosamente, procurando me orientar no cipoal de minhas contradições. [...]

Aos poucos fui passando das questões artísticas ou meramente estéticas para os problemas pessoais. Deveria ou não aceitar aquele emprego? Resistiria às tentações da facilidade, por mim confundida, segundo ele, com um falso conceito de felicidade? Em outras palavras: 0 casamento em perspectiva, sendo eu tão jovem, não seria fatal para a minha vocação de escritor? (SABINO, 1996, p. 99).

Nesse momento do perfil, observamos semelhanças entre a narrativa de "Improviso do amigo morto" e o romance $O$ encontro marcado: as incertezas que afligiam o narrador-personagem Fernando Sabino na juventude parecem as mesmas que angustiam Eduardo Marciano, a ponto de surgir em nós a seguinte questão: o texto é mesmo sobre Mário de Andrade ou sobre Fernando Sabino quando jovem? Ou, ainda, sobre a recriação, no presente, do próprio autor quando jovem?

$\mathrm{Na}$ verdade, "Improviso do amigo morto", mais do que falar sobre Mário ou Fernando, aborda a intensa amizade entre os dois escritores, a importância e a influência que o "papa" do modernismo teve na vida e na obra de Sabino.
$\mathrm{O}$ autor, em tom elogioso, narra uma situação que o deixou decepcionado com Mário de Andrade. O missivista teria recusado o convite de ser padrinho de casamento de Fernando Sabino. Com o passar do tempo, entretanto, Sabino percebe o real motivo da recusa. Ao transpor tal situação para a narrativa, Sabino oferece ao leitor o lado mais humano do escritor paulista:

[...] quem vivia praticamente da mão para a boca, conforme ele próprio fazia saber em suas cartas, sobrevivendo à custa de parca remuneração pelo trabalho de professor e pelos seus artigos em jornais e revistas, quem às vezes não tinha nem como pagar o selo da correspondência mais avultada, quem não dispunha de recursos para uma simples viagem de São Paulo para o Rio, não poderia enfrentar por conta própria transporte e hospedagem em Belo Horizonte, ser padrinho de um solene casamento realizado em ambiente oficial no próprio Palácio do Governo, vestido no mínimo de fraque. E ainda por cima arcar com um presente que, a seus olhos, fosse digno de tão altas paraninfagens. [...]

Não se humilhou nas explicações que me deu, não era do seu feitio. Mas hoje posso ver de maneira bem simples que seus empecilhos deviam ser de ordem material - nem por isso menos respeitáveis. $\mathrm{E}$, de certa maneira, meu respeito e minha estima por ele aumentam ainda mais (SABINO, 1996, p. 100-101).

Assim como o perfil de Mário de Andrade, todos os textos reunidos em Gente assumem, como já observamos, um caráter híbrido. Essa hibridização ultrapassa o problema da biografia e da ficção, alcançando outros dois compostos: biografia e autobiografia e, também, jornalismo e literatura. 
A combinação entre biografia e autobiografia ocorre na medida em que, para cada perfil delineado, constrói-se um segundo: o do próprio autor. E, entre jornalismo e literatura, em razão da publicação original dos perfis. Esses textos foram escritos inicialmente para a imprensa; no entanto, ao serem transferidos para o livro, transcendem seu caráter efêmero, demonstrando qualidade literária.

A verve autobiográfica de Fernando Sabino era de tal modo atuante que a reinvenção de sua própria vida parece não ter sido suficiente para ele. Foi necessário, então, recriar outras vidas. Ao menos é o que podemos notar nos quarenta e quatro perfis que compõem Gente. Assim, podemos concluir que, experiência pessoal e representação literária sempre foram os temas que ocuparam o campo de atuação do escritor.

\section{Considerações finais}

Os textos que misturam experiência pessoal e ficção ocupam, na atualidade, um espaço expressivo nos estudos literários, visto que as renovações e produções no campo das escritas de si avolumam-se sobremaneira e não ameaçam cessar. Nesse contexto, considerou-se pertinente analisar a obra do escritor Fernando Sabino devido à notável tendência autobiográfica de sua literatura e ao caráter ambíguo dos textos do autor ao aproximarem vida e criação literária.

Nem mesmo a "autobiografia" de Sabino afastou-se do caráter híbrido de sua literatura, pois, como observamos, o próprio título atribuído ao livro, $O$ tabuleiro de damas, além da ideia de um jogo entre o autor e o leitor, remete a uma impossibilidade de encontrarmos a verdade por meio do real. A verdade, segundo o autor, só pode ser alcançada por meio da imaginação. Esses aspectos, somados a outros, como a definição de "esboço" conferida ao livro, os questionamentos levantados sobre realidade e ficção ao longo do texto e as alterações realizadas em edições posteriores da obra, esgarçam o pacto autobiográfico estabelecido com o leitor.

A oscilação entre realidade e ficção, entretanto, não parece ser provocada pelo autor quando a narrativa aborda a formação literária. Nesses momentos, observamos a manutenção do pacto autobiográfico (identidade entre autor, narrador e personagem), até porque essa estabilização é importante para a imagem de si que o autor deseja construir.

Esse hibridismo característico dos textos autobiográficos de Fernando Sabino é observado também no livro de perfis do autor. Parece que o interesse em recriar experiências pessoais por meio da arte fez o escritor exceder a sua própria vida e elaborar também a de outros escritores, como acontece em Gente. A proposta do livro é apresentar aos leitores pequenas biografias de personalidades que fazem parte do universo pessoal e artístico de Fernando Sabino. No entanto, como vimos, não é possível ao autor apagar-se. Desta forma, en- 
quanto descreve o outro, Sabino também fala de si, terminando por misturar biografia com autobiografia.

Lives as an invention product: an analysis of Fernando Sabino's writing as a biographer and autobiographer

\section{Abstract}

This article aims to contribute to the research within the scope of the self-writing through the analysis of the work by (the writer) Fernando Sabino, author who made constant use of life as a literary invention product. For such purpose, the autobiographical tenor pervading the work by the writer from Minas Gerais will be investigated from two of his books: the autobiography draft $O$ tabuleiro de damas (1988) and the profiles book Gente (1975). In the autobiography, we will notice that Fernando Sabino privileges the account of his literary experiences to the detriment of his personal ones, thereby contributing to the construction of an authorial image: the biographical one. In several passages of the narrative it is possible to verify, too, the focus shift to the description of other personalities wheras in the book Gente, in which the intent is to evince the other, there is, quite often, the representation of the writer. Thus, this paper is not limited to Fernando Sabino's autobiographical writing, it also analizes another facet of the author: the biographical one.

Keywords: Fernando Sabino. Autobiography. Biography. Self-image.

\section{Referências}

ARFUCH, Leonor. O espaço biográfico: dilemas da subjetividade contemporânea. Rio de Janeiro: EDUERJ, 2010.

BAUMAN, Zygmunt. Identidade: entrevista a Benedetto Vecchi. Trad. Carlos Alberto Medeiros. Rio de Janeiro: Zahar, 2005.

BETELLA, Gabriela Kvacek. A lealdade da busca: Fernando Sabino fala sobre os outros e encontra ele mesmo, ou vice-versa. Ipotesi, Juiz de Fora, v. 9, n. 1-2, p. 123-124, jan./ jun., jul./dez. 2005. Disponível em: <http:// www.ufjf.br/revistaipotesi/files/2011/05/12-A-lealdade-da-busca.pdf $>$. Acesso em: 10 nov. 2014.

BLOCH, Arnaldo. Fernando Sabino: reencontro. Rio de Janeiro: Relume Dumará, 2005.

CANDIDO, Antonio. A vida ao rés-do-chão. In: SABINO, Fernando et al. Para gostar de ler: crônicas. São Paulo: Ática, 1979. p. 5-13.

KLINGER, Diana. Escritas de si, escritas do outro: o retorno do autor e a virada etnográfica. 2. ed. Rio de Janeiro: 7Letras, 2012.

LEITE, Dante Moreira. Ficção, biografia e autobiografia. In: LEITE, Rui Moreira (Org.). O amor romântico e outros temas. São Paulo: Unesp, 2007. p. 43-52.

LEJEUNE, Philippe. O pacto autobiográfi$c o$ : de Rousseau à internet. Belo Horizonte: UFMG, 2008. (Organização de Jovita Maria G. Noronha).

MAINGUENEAU, Dominique. Imagem de autor: não há autor sem imagem. In: Doze conceitos em análise do discurso. São Paulo: Parábola, 2010. p. 139-156.

MIRANDA, Wander Melo. A ilusão autobiográfica. In: Corpos escritos. São

Paulo: Edusp; Belo Horizonte: UFMG, 1992. p. 25-41. 
MOLLOY, Sylvia. Vale o escrito: a escrita autobiográfica na América Hispânica. Chapecó: Argos, 2003.

ROCHA, Fátima Cristina Dias. Manuel Bandeira e as memórias de um simples poeta lírico. In: CHIARA, Ana; ROCHA, Fátima Cristina Dias (Org.). Literatura brasileira em foco: escritas da intimidade. Rio de Janeiro: Casa Doze, 2009. p. 65-82.

SABINO, Fernando. Gente. Rio de Janeiro: Record, 1996.

. $O$ encontro marcado. 90 . ed. Rio de Janeiro: Record, 2010.

. O tabuleiro de damas. 5. ed. Rio de Janeiro: Record, 1999.

. Os quatro mineiros do apocalipse. Entrevista coordenada por Narceu de Almeida Filho para Ele e Ela, 1979. In:

Cartas na mesa. Rio de Janeiro: Record, 2002. p. 303-315.

Um escritor na biblioteca: Fernando Sabino. Curitiba: BPP/SECE, 1985. 